\title{
Appealing to women
}

Some months before the 1959 general election, Labour's keenest women activists were told by one of their leading lights that they needed to accommodate 'a new generation, with new habits, new interests, and new reactions to the political problems of the day'. ${ }^{1}$ The result in October appeared to confirm her analysis, as many observers believed a significant cause of Labour's defeat was its rejection by younger, affluent female voters.

If the problem appeared acute in the late 1950s, the party had always found it hard to convince women to vote Labour at the same rate as men. Historians explain this 'gender gap' by suggesting that, as a maledominated organisation, Labour's perception of its overall purpose meant it did not take women's discrete interests seriously. ${ }^{2}$ In contrast, the Conservatives are considered to have been more willing and able to focus on matters relating to women's prevailing home-making role. ${ }^{3}$ As outlined in Chapter 3, however, Labour's 1959 campaign gave domestic issues some prominence. So far as Gallup was concerned, the gender gap nearly halved compared with 1955 , so that only 5 per cent more men than women supported the party (see Table 3.1, p. 63). During the 1960s Transport House endeavoured to make Labour more attractive to young wives and mothers, such that in 1964 Harold Wilson claimed he would return Labour to power on the back of a 'women's crusade'. ${ }^{4}$ Paradoxically, the gender gap actually doubled between 1959 and 1964 and stood at 8 per cent in 1966 .

Despite official strategy, most male members continued to think their party's main purpose remained that of improving the position of male manual workers. But so did many female activists. Delegates to the 1959 national conference of Labour women had spent little time discussing consumer issues; instead, speeches were dominated by the spectre of rising male unemployment. ${ }^{5}$ If the party's union connection encouraged this emphasis, it was also because such women were mostly members of households whose welfare relied on a husband's continued employment. So far as they were concerned, despite the increasing importance of 
domestic consumption and the rising number of wives entering paid employment, women as a whole remained dependent on male breadwinners.

This chapter first outlines the place of women in the party at the start of the 1960s, to locate subsequent events in their proper context. It focuses on Labour's response to women's changing place in society by looking at how officials promoted a variety of organisational reforms designed to increase the number of younger female members. The chapter then discusses Labour's efforts to come to terms with the perceived need to address gender inequality in the later part of the decade, especially with regard to equal pay. It does not dispute the predominant view that Labour was largely run by - and to some extent for - men, something which was also true of most other civil institutions during this period, including the Conservative Party. However, it seeks to stress the often obscured fact that, while much keener to promote equal pay than the leadership, Labour's women activists were in other respects broadly content with the party's emphases. Indeed, so far as attempts to increase the party's appeal to younger working wives and mothers were concerned, they often proved to be an impediment. Furthermore, Labour's women also blamed members of their own sex as much as or more than men for inequalities feminists would subsequently deem to be the result of 'patriarchy'.

\section{Labour's women}

While issued with a different-coloured membership card - which some thought denoted their second-class status - women could participate in the party just like men. They also had an additional means of working within Labour's ranks, which granted them, should they desire it, a separate voice. Thus, by 1965, 85 per cent of constituencies had at least one women's section. Apart from giving women a distinct platform they could send representatives to meetings of the constituency's general management committee (GMC) - women's sections were meant to reflect their particular interests. ${ }^{6}$ To encourage the growth of sections, each region was allotted a women's organiser, who operated under the direction of the Chief Women's Officer (CWO), based in Transport House. To co-ordinate activities, sections in more than one constituency were gathered together into constituency committees within urban districts and federations in counties. These appointed delegates to regional women's advisory councils, which, in turn, sent representatives to the National Labour Women's Advisory Council (NLWAC), serviced by the CWO's department, which also organised the annual national conference of Labour women. The function of the NLWAC was, as its title implied, 
Table 5.1 Labour's official female membership, 1960-70

\begin{tabular}{lcc}
\hline & Official figure & Percentage of membership \\
\hline 1960 & 330,608 & 41.8 \\
1961 & 316,054 & 42.1 \\
1962 & 322,883 & 42.1 \\
1963 & 349,707 & 42.1 \\
1964 & 351,206 & 42.3 \\
1965 & 341,601 & 41.8 \\
1966 & 320,971 & 41.4 \\
1967 & 306,437 & 41.8 \\
1968 & 299,357 & 42.7 \\
1969 & 292,800 & 43.0 \\
1970 & 285,901 & 41.4 \\
\hline
\end{tabular}

Table 2.1 (p. 43) gives total party membership.

Source: Labour Party conference reports, 1960-70.

to advise the National Executive Committee (NEC) on matters of importance to female members. Five members of the NEC were elected by party conference from a women-only list, as a consequence of which they owed their places to the unions rather than the support of other women. While the NEC was under no obligation to heed their lobbying, women at least had the chance to make their collective voice heard.

According to official figures, in 1960 there were 330,608 female party members, accounting for 41.8 per cent of the total, a proportion that hardly varied during the decade (see Table 5.1). In the unlikely event these figures reflected reality, women were under-represented, a feature that became much more pronounced higher up the party hierarchy. Thus, in late 1950s Manchester, only one-quarter of ward secretaries were women. ${ }^{7}$ During the 1960s the proportion of female constituency Labour party (CLP) secretaries and delegates to annual conference remained steady, at 15-20 per cent. The extent of their lack of presence varied across the country, although everywhere it was striking. In rural areas, where Labour had never done well, female secretaries were rare, but that was also the case in most industrial counties. ${ }^{8}$ The position was even worse in the Commons. In 1959 only thirty-six women stood as parliamentary candidates, a mere 5.8 per cent of the total: the number elected came to a paltry thirteen. Women Labour MPs continued to be a tiny minority and while the 1966 landslide saw their number reach the dizzy height of nineteen (or 5.2 per cent), in 1970 this fell to ten. During the course of the 1964-70 governments there were never more than six female junior ministers, while their representation around the Cabinet table was mostly limited to Barbara Castle, although Judith Hart joined her in 1968. 
Despite this, the 1955 Wilson report on party organisation (see Chapter 2) claimed women supplied the majority of CLP volunteers; and Brixton's agent declared in 1956 that, 'if one of our active lady members has a baby we begin to get nervous about the ward organisation' ${ }^{9}$ Responsibilities were, however, generally allocated on the basis of conventional gender roles, which led some to complain that women were confined to catering for, and cleaning up after, male-dominated meetings. That a significant number of activists were married to each other clearly influenced matters. ${ }^{10}$ Labour husbands and wives related to one another in the party as they did at home and domestic relationships largely reflected established gender norms. Thus, during the 1959 campaign, most women in Southall placed leaflets into envelopes, while safely seated in party offices, while their men-folk took to the streets. ${ }^{11}$ Similarly, during the 1960s, Bristol South women supplied only one-fifth of the CLP's membership fee collectors. ${ }^{12}$

By no means were all female activists frustrated by this clearly gendered division of labour; some appeared to see it as part of their 'natural' lot. For instance, those in Brecon were annoyed after a member of the constituency's executive committee (EC) complained about a dirty party room. Their anger was, however, not due to his assumption that their job was to clean the room, but because they had not been informed earlier that it required attention. ${ }^{13}$ There were, nonetheless, some occasions when women members asserted themselves. Most famously, Castle owed her position as a Blackburn MP after 1945 to them threatening to stop making tea for CLP meetings unless one of their kind was shortlisted for consideration as a parliamentary candidate. ${ }^{14}$ More prosaically, women on Llanelli's GMC cast their own modest version of the block vote to maximise female representation on its EC. ${ }^{15}$ When one leading female activist was not selected as a candidate for local office in Swansea, she went so far as to stand as an independent. Owing to a collective frustration with their ward's lack of regard for the women's section, eleven other female activists supported her campaign. ${ }^{16}$

If nothing else, the range of issues discussed by at least some sections was impressive. In Bradford South during 1958, for example, women debated home safety, local landmarks, 'problem' families, welfare, a member's Mediterranean cruise and Labour's new leisure policy. ${ }^{17}$ In the same year, those in Clapham talked about local government, rents, the Soviet Union, the work of magistrates, local elections, delinquent children and education. To make them more agreeable, as well as discussions the Clapham meetings featured raffles, performances of short plays or games of 'housey-housey'. ${ }^{18}$ In contrast, other sections were almost entirely preoccupied with raising money for the CLP, through jumble sales and summer fetes. ${ }^{19}$ Whatever they did, sections reflected the interests of those full-time housewives who generally attended meetings. 
Table 5.2 Women's section delegates attending the national conference of Labour women, 1960-70

\begin{tabular}{lccc}
\hline & $\begin{array}{c}\text { Number of } \\
\text { sections }\end{array}$ & $\begin{array}{c}\text { Number of section } \\
\text { delegates at conference }\end{array}$ & $\begin{array}{c}\text { Percentage of sections } \\
\text { sending delegates }\end{array}$ \\
\hline 1960 & - & 398 & - \\
1961 & 1,564 & 358 & 22.9 \\
1962 & 1,580 & 330 & 20.1 \\
1963 & 1,613 & 461 & 28.6 \\
1964 & 1,640 & 478 & 29.1 \\
1965 & 1,660 & 438 & 26.4 \\
1966 & 1,646 & 300 & 18.2 \\
1967 & 1,603 & 333 & 20.8 \\
1968 & 1,541 & 313 & 20.3 \\
1969 & 1,420 & 286 & 20.1 \\
1970 & 1,373 & 221 & 16.1 \\
\hline
\end{tabular}

Note: After 1963 each section was entitled to send a delegate; before this, representation was based on constituency (i.e. groups of sections).

Source: Reports of the National Conferences of Labour Women, 1960-70.

Even so, while in the Grimsby women's section there were women 'who really enjoy being housewives' and believed a 'happy home should be our first aim', even they did not go as far as Morden members, who dedicated one gathering to a washing machine demonstration, to which they brought dirty clothes. ${ }^{20}$ It is deceptively easy to denigrate the modesty of these activities. Some nonetheless argued - as did the South West Region's women's organiser - that less 'politically minded' women required sections. ${ }^{21}$ They gave them the chance to learn about society, gain an insight into political issues and provided a platform to campaign on matters about which they cared. As one participant recalled, sections gave those 'too nervous' to attend meetings dominated by men the chance to build confidence so they might eventually become more directly involved in the wider party. ${ }^{22}$

Even more than wards and CLPs, women's sections were predominantly parochial in orientation. At least one-third did not take a copy of the monthly journal produced by Transport House, Labour Woman, whose circulation hovered around 10,000 during the 1960s. ${ }^{23}$ Most failed to send delegates to their own national conference: it was a rare year that saw more than 20 per cent represented (see Table 5.2). This might have been partly due to lack of funds but was probably mainly accountable to the older age of many Labour women. Since the early 1950 s the party had lost younger female members to paid employment, while even part-time work reduced the hours previously committed housewives with children could devote to the cause. ${ }^{24}$ Thus, by the late $1960 \mathrm{~s}$, members 
of the women's section in Hammersmith North had an average age of seventy-two, while those in Oxford were too frail to attend meetings held in the city centre. ${ }^{25}$ One regional advisory council was even described in 1966 by its former secretary as serving 'little useful purpose, political or otherwise except keeping the older Labour women together occasionally - it's the Mother's Union of the Labour Party'. ${ }^{26}$

\section{Reforming the organisation}

By the start of the 1960s, some in Transport House, such as Len Williams, the National Agent, believed there was no need for women to have their own 'political kindergarten', as they had largely achieved equality. ${ }^{27}$ For similar reasons, the 1968 Simpson report on party organisation (see Chapter 2) recommended that those NEC seats reserved for women should be redistributed among the unions and constituencies. Like Williams, Simpson believed Labour women could stand on their own two feet without special assistance, although delegates to the Labour women's conference were less confident. ${ }^{28}$ Simpson's proposal was rejected, possibly because it threatened to enhance the voice of the left on the NEC rather than because of NLWAC representations. ${ }^{29}$ In 1961 the CWO's department was subsumed within that of the National Agent and while the title of Chief Women's Organiser remained, as did the regional women's organisers, post-holders ceased to act independently of male officials. Some on the NLWAC were convinced this was due to a desire to place women under the authority of 'Men Organisers'. Reformers nonetheless claimed change would ensure everybody in the party took raising female membership seriously, but agreed Labour should still cater for women's 'special interests'. ${ }^{30}$

It was not just men who doubted the efficacy of Labour's separate women's organisation. Some women, usually younger and more educated than most, had long called for its abolition, if only because members of the sections lacked what they considered to be an adequate interest in politics. In the late 1940s, for example, one critic described her north London section as a 'cross between a rummage sale and a tea-party'. ${ }^{31}$ Some middle-class CLPs, such as Bristol West, even thought sections prevented women's integration into party life. As neighbouring Bristol North West's agent stated, 'modern woman' refused to be 'segregated' and was not prepared to 'sit back and be regarded as a useful adjunct to the Party making tea'. Instead, she wanted 'to play a full part in the Movement, a "man's" part'. ${ }^{32}$

In 1967 the women's conference debated a motion that advocated its own abolition, tabled in the belief that this would allow women to participate in the party on equal terms with men. Those who drafted 
the motion thought there were no 'subjects which were particularly suitable for women to deal with': men and women 'were equally concerned with all matters because they lived in the same world and their basic problems were the same'. The overwhelming majority present nonetheless considered the conference remained the only occasion on which women's problems could gain a proper hearing. As one put it, Labour was the 'most masculine dominated and masculine orientated movement' she had ever encountered. ${ }^{33}$ A similar motion was debated the following year; it was moved by a young delegate who declared that, to those of her generation, sections appeared to serve 'no apparent purpose [other] than to bring together like minded people for pleasant, if rather aimless social occasions'. ${ }^{34}$ While this view was again rejected, some continued to imagine that the very existence of women's sections perpetuated discrimination, as they gave some men the excuse they needed to deny women a proper say in the party as a whole..$^{35}$

Despite these challenges, the prevailing view among those 300 or so women who attended their national conference during the late 1960s was that, as one put it, women were 'equal but different'. They still required a separate organisation because their 'unique function', as the NLWAC later had it, that of child-bearing, placed them at an inherent disadvantage. Thus, while Labour was unable to overcome the social consequences of biology, it should still cater for difference. Consequently, while most women preferred to be treated as individuals rather than 'women', they still needed 'preferential treatment'. ${ }^{36}$

\section{Attracting younger women}

It was never thought that encouraging younger women into the party would be easy. They were widely considered 'too busy to think much about politics' and would first have to be persuaded that their interests were indeed 'political', and only then that Labour membership could advance them. ${ }^{37}$ Moreover, as one activist noted, those working outside the home, or looking after their family full-time, wanted to be 'lifted out of themselves' and did not 'want to read correspondence and discuss political issues all night'. ${ }^{38}$ Sections were consequently asked to streamline routine business. As Mary Sutherland, Labour's long-standing CWO until she retired in 1961, declared, 'it is more important to double our membership and double attendances at meetings than to insist that every member shall discuss items of business' ${ }^{39}$ With that object in mind, women were urged to experiment with more appealing social activities, such as sherry parties and theatre trips. ${ }^{40}$

It would have surprised some critics that women's sections needed to enhance their social side. In any case, such was the target group's 
presumed resistance to formal political activity that officials' emphasis lay more on encouraging Labour women to pursue 'informal' activities outside the section structure, such as luncheon, dinner and supper clubs, coffee circles, 'young mums' clubs and neighbourhood groups. ${ }^{41}$ The overt purpose of these initiatives was to bring Labour women into contact with friends and neighbours so they might enjoy a 'pleasant social gathering'. Covertly, however, they were meant to develop into opportunities for 'useful political discussion and membership recruitment'. ${ }^{42}$ Members were warned they might be forced to participate in idle gossip about this T.V. programme or that', so they could put Labour's case at an appropriate moment. ${ }^{43}$ With this strategy of permeation in mind, a Middlesbrough activist went so far as to urge Labour women to 'get into any organisation, no matter what - they could go and talk tiddly-winks provided they got on to Labour policy in the end'. ${ }^{44}$ Young mothers were pursued with particular zeal. In Bradford members converted a garage so it could house a playgroup and in Bletchley women ran a playgroup which, after three years, catered for 271 children. Women in Halesowen were so successful in attracting young mothers that meetings were overrun by noisy toddlers - it became difficult to discuss anything, let alone politics. ${ }^{45}$

Labour women were also urged to take up popular non-partisan issues to place themselves in a more attractive light; a national effort to raise money for Freedom from Hunger (devoted to helping developing nations) in 1963-4 had this as its object, while in Stirling women established a presence on a new housing estate by collecting for people with disabilities. In Ipswich they organised a retail price survey to demonstrate Labour's sympathy for housewives, something undoubtedly behind a national campaign promoting consumer protection during 1962-3. ${ }^{46}$

In spite of official exhortation, few sections were keen to encourage a greater role for young women. ${ }^{47}$ There were too many, such as the one in Toxteth, Liverpool, where a dwindling band of the aged few occasionally noted the reluctance of youngsters to attend their afternoon get-togethers. Members did not think they could do much about this, and blamed it on the rising number of married women in paid work and the spread of television ownership. It is likely they believed that, if anybody was to blame for Labour's lack of younger female members, it was women themselves. ${ }^{48}$ In truth, many established activists were too comfortable with their cosy gatherings - sharing gossip about old acquaintances and listening to the occasional educational talk - to want to change. Unfortunately, few twenty-somethings found 'houseyhousey' an attractive prospect, while many others were, for work or domestic reasons, simply unable to attend afternoon meetings.

In trying to enthuse sections to recruit younger women, officials confronted a generational divide that reflected tensions evident on 
numerous working-class housing estates. ${ }^{49}$ Many Labour women looked on their less mature, non-party counterparts as in need of instruction rather than the indulgence of a glass of sherry. Like the archetypal matriarch in 'traditional' proletarian communities, Labour women expected to be listened to and learnt from. ${ }^{50}$ At least some lacked sympathy for the plight of those to whom they were meant to appeal. Women in Grimsby, for example, were sceptical about whether young mothers should go out to work and believed that 'nothing, however good it may be, is as good as a mother's care'. ${ }^{51}$ Young women were also, according to the MP Lena Jeger, that part of the population 'most careless of its rights of franchise and citizenship' and the 'laziest of all groups in doing their duty at the polls'. ${ }^{52}$

This rift was revealed most clearly during women's conference debates on consumer protection. While all speakers favoured increasing help and advice, this was often presented as giving aid to naïve young wives, who, as one speaker put it, did not have the 'guts' to shut the door in the face of predatory door-to-door salespeople and 'tell them where to get off'. After hearing various tales of women buying shoddy goods, another declaimed, 'what gullible people women were', and stated that those buying goods on hire purchase were also 'playing the Tory game'. A further speaker wondered 'what kind of fools and mugs housewives were'; she considered it impossible to protect some from their own foolishness. ${ }^{53}$ One even wondered, possibly thinking of fellow Labour women as the prototype, 'what had become of the wise housewives of the past, who had known exactly what a shilling meant'. Even the fact that 'modern food ... was not worth eating' was partly women's own fault, for they bought frozen food because it was quick and easy to cook. ${ }^{54}$ That those few youngsters attending conference usually confirmed this picture did not help. As one said, she belonged to that 'deluded generation' who thought unemployment could never happen to them and who had 'bought their washing machines and their tellys, egged on to live right up to their income'. ${ }^{55}$

In light of this hostility, some officials came to believe it necessary to devise a new organisation, just for younger women. ${ }^{56}$ Raising similar concerns generated by Tony Benn's Citizens for Labour (see Chapter 3), the NEC initially turned down the request of reformers in Buckingham to allow the Socialist Women's Circle to affiliate to their CLP. The Circle was organised by party activists; while its mostly non-partisan members mainly engaged in its social activities, they helped with electoral work when required. Despite this, the NEC believed such women should join sections and become fully integrated into the party. ${ }^{57}$ The promotion of women's councils in the late 1960s marked a dramatic change of tack, being - contrary to officials' claims - an attempt to reduce the influence of elderly stalwarts based in sections. ${ }^{58}$ These councils were to assume 
the co-ordinating role formerly performed by constituency committees, federations and advisory councils, bodies that only reflected section opinion. Councils would represent non-members who belonged to those 'informal' bodies - such as luncheon clubs and neighbourhood groups - established after 1959. Officials hoped this new 'outward looking structure' would finally enable the party to pursue more nonpartisan 'community' activities and finally bridge the gap between Labour women and those active in less overtly political groups. ${ }^{59}$

\section{Labour women and feminism}

When Maureen Colquhoun entered the Commons in 1974, she claimed to find no 'feminist' women Labour MPs. If several sought to improve their sisters' lives, she claimed none wanted to dismantle the 'patriarchal society' - if only because they had not heard of the term. ${ }^{60}$ That 'patriarchy' had no purchase among Labour's female MPs should have come as no surprise to Colquhoun, who had attended women's conferences during the 1960s. While activists supported greater equality, few believed male and female interests were inherently in conflict. ${ }^{61}$ Hence, reflecting the majority position, Sutherland rejected the notion of an identity of the sexes', on the basis that the genders performed different but complementary roles, with women's key responsibility lying in the home. ${ }^{62}$

Some historians have stated that, for much of the post-war period, there was little evidence of a clear 'ideology of gender' among Labour's female activists, with the 1950s and 1960s being described as the 'nadir of women's equal rights' in the party. ${ }^{63}$ That is going too far, as some at least believed male prejudice impeded the development of full gender equality, in Labour's ranks as much as anywhere else. One delegate to the women's conference, for example, said men considered women capable only of 'making tea, etc., trotting round streets and sitting in committee rooms'; a second claimed they only paid 'lip-service' to equal rights; men, another complained, 'simply did not want women to have equality'. ${ }^{64}$ How far sections believed male prejudice prevented women assuming a prominent role in the party was measured by a survey conducted during 1968 to discover what they thought about women's position in public life. Leaders on the NLWAC expressed some alarm at the 'reasonableness' of the outlook revealed and accused sections of complacency. The survey indicated that, if Labour women were aware that male bigotry was one cause of women's modest public profile, most believed it was largely due to women's own shortcomings. They also reportedly neither expected nor even desired a substantial change in female under-representation; most apparently merely requested men's 'respect'. ${ }^{65}$ In certain CLPs, respect would have been welcome: in at 
least one Yorkshire mining constituency, male members were said to react to female contributions to debate with 'amused tolerance'. ${ }^{66}$

It was a very rare constituency party that thought it necessary actively to promote women candidates. Largely middle-class Bristol North West was one of the few. In 1968 its GMC aimed to 'groom' women to ensure every ward was represented by at least one female Labour councillor. ${ }^{67}$ For the most part, rather than reform the party's procedures to challenge the imbalance between men and women, the latter were exhorted to push themselves forward to beat men at their own game. Doris Fisher, one of the few women returned to the Commons in 1970, considered the basic reason for their under-representation was that politics was a 'tough, rough business where very often feelings are hurt'. Many women were, she judged, 'personally sensitive', so did not wish to enter the fray: Fisher advised them to 'adopt a "thick skin"”. Her words echoed those of a councillor who suggested women needed to acquire the 'skin of a rhinoceros' and 'show the men they were equally capable of conducting the country's affairs' ${ }^{68}$

Others argued that 'men were not the ogres women made them out to be', and claimed that the 'biggest enemies of women were women themselves', as they were often biased in favour of male candidates. It was the minister Peggy Herbison who said that because 'too many women electors were against having women in politics', they should accept 'a great deal of the responsibility' for their own under-representation. ${ }^{69}$ The NLWAC believed women in general 'disliked female managers, courted male patronage, rather than male competition, and when patronized by men accepted it without complaint'. ${ }^{70}$ Ultimately, one activist argued, 'women themselves were responsible for most of the discrimination against their sex' because it 'began in the home where the small daughter was given the washing up to do while her brother was handed his fishing rod'.'Equality for women', it was said, 'began in the hearts of women themselves'. ${ }^{71}$

\section{Studying discrimination}

Despite this voluntaristic emphasis, as the decade drew to a close, some in the party became more conscious of the structural inequalities that distinguished the genders. On a superficial level, an increasing number of CLPs passed resolutions demanding that the 'archaic custom' of differently coloured membership cards be abandoned. East Ham North had been the first to make this proposal, in 1958, but it was only in 1970 that, despite the loss of a means of assessing how many women belonged to the party, the NEC agreed to issue a single style of membership card in future. ${ }^{72}$ 
More substantively, in July 1967 the NEC's Home Policy Subcommittee formed the Discrimination Against Women Study Group, charged with the aim of influencing policy. ${ }^{73}$ In the end, the Group's output was so limited its impact was negligible, although its deliberations do illustrate how some of its leading members viewed the subject. The Group was drawn from the NEC and the Commons, as well as outside experts, and the importance attached to its deliberations was signified by the fact that Douglas Houghton was the chair. Houghton was an important figure, who had just left the Cabinet, who chaired the Parliamentary Labour Party and, in the wake of George Brown's final resignation, who was mooted as a possible deputy leader. More pertinently, Houghton had overseen a ministerial review of the social services and, as he put it, 'social security is mostly about women'. ${ }^{74}$

The Group's remit was ambitious - overly so, as it included a 'comprehensive study of the nature of discrimination against women', so that it could recommend policies that would help achieve equal rights. There was, from the outset, no question that women did suffer 'downright injustice'. Despite this, members rejected the 'standpoint of feminism' and instead proceeded on the basis that 'a country that designates any group, class, or sex as second class citizens will in the long run suffer by denying them a full contribution to society'. While agreeing about the reality of discrimination, the Group was divided over how to overcome it. Members' initial focus fell on tax, in particular the fact that wives were assessed as their husbands' dependants. As early as January 1968, Houghton suggested couples should be treated separately, as he considered the existing arrangement 'derogatory' to women's 'dignity as individuals'. Because some thought this would leave poorer families worse off, he did not prevail. The former minister Peggy Herbison even questioned why full-time housewives should be given the same social security benefits as men, given that they made fewer contributions, through their absence from paid employment. Women, she believed, 'could not expect both to have full social security rights and to opt out of contributions', her implication being that housewives should pay National Insurance. As Herbison told the 1968 national conference of Labour women, 'if women wanted equality they had also to accept the responsibilities of equality'. ${ }^{75}$ On both subjects the Group found it hard to reach agreement and the tax question was unresolved when Wilson announced the date of the 1970 election.

An important by-product of the Group's work was Participation '69 (discussed in more detail in Chapter 8), which was a scheme meant to promote greater membership involvement in policy-making. The first subject used to test party opinion was women and social security, on which the Group had just produced an interim report. Members were asked for their thoughts on this in light of changing family relationships, 
which were said to be encouraging increasing independence and equality' for wives, while single mothers apparently accounted for a rising proportion of those in receipt of supplementary benefit. It was calculated that the opinions of 2,343 members were represented by the responses sent to Transport House. While these cannot be assumed to be representative, they give some indication of thinking in the wider party. Respondents overwhelmingly believed women should be treated the same as men when it came to tax, while there was little sense that unmarried mothers were less 'deserving' of benefits than their married equivalents. Some, however, disliked what they took to be the assumption behind the exercise, which, they believed, was that all women should be in paid employment. Leyland Trades Council, for example, stated that it was 'not conducive to good quality family life' for mothers of children under twelve to work outside the home. ${ }^{76}$

The Study Group had lost its way some time before this broad endorsement of its work. Reflecting its lack of direction, the last gathering before the 1970 election was presented with a historical analysis of female emancipation, which concluded that any discussion of women's social position should be preceded by an examination of their sexual relationships. For a body that had been in existence nearly two and half years, this was a bizarre time to consider first principles. Whether the Group's failure to come to firm conclusions about particular subjects was due to its original remit or a lack of consensus over detailed policy is not clear. Houghton's chairing certainly did not help: significantly, his earlier review of the social services was criticised for its production of overly detailed papers but lack of compelling general purpose, something that also characterised the Group's slight output. ${ }^{77}$

\section{Labour women and working women}

The Wilson governments introduced numerous pieces of legislation meant to improve women's lives, most obviously its 'permissive' reforms, which liberalised access to abortion and divorce. On the former issue in particular, while broadly in favour of reform, the party still faced a number of ways. ${ }^{78}$ A delegate to the 1970 women's conference probably spoke for the majority when she declared that 'everyone should be thankful for a permissive society which threw open the doors and let out the fear of the unknown and let in the fresh air of commonsense'. She did not, however, speak for the Burnley delegate, who could not believe all those present fully supported the 1967 Abortion Act and whose concern with the supposed abuses to which it gave rise echoed that of some NLWAC members. ${ }^{79}$ 
So far as an increasing proportion of women were concerned, however, the most significant measure passed by the Labour administration was the 1970 Equal Pay Act. A series of articles published in Labour Woman before the 1959 election took as their theme 'women and the second industrial revolution' and outlined how the automation of production might affect them. The author correctly predicted there would be a rise in the number of jobs in the service industry, but erroneously believed this would not create a greater demand for female workers. Instead, she considered it probable that, as men's real wages rose through greater productivity, there would be less need for women to seek work outside the home. This, together with the wider availability of domestic labour-saving devices, led her to hope women would enjoy more leisure and so assume a more prominent public role. ${ }^{80}$ As many women's sections were beginning to learn to their cost, women were already filling the expanding number of job vacancies caused by full employment. To meet this demand for female labour, some believed, women would have to be treated - or at least paid - the same as men. Yet, as late as 1969, Joyce Gould claimed on behalf of the NLWAC that they remained 'the slave labour of the 1960's' and 'waited for their Wilberforce to come and rescue them'. ${ }^{81}$

Labour women were in at least two minds over female employment. Some adhered to a belief in the hierarchy of need, so that, in 1959, a year when unemployment was thought to be on the rise, the women's conference debated a resolution demanding that employers made married female workers redundant before single women. ${ }^{82}$ At their 1960 conference, Ron Hayward, who would become General Secretary of the Labour Party in 1969, informed delegates that if Labour had lost the previous general election because 'Jack was all right', Jack was in this happy state only because 'Mrs. Jack had a part-time job in order to maintain her family's standard of living'. Hayward's inference was clear: men should be paid enough so that their wives did not have to work. At least some women agreed, believing in 1964 that 'women only worked because they were desperate for the money'. ${ }^{83}$ As one NLWAC speaker noted, 'the most important thing in the homes of the people was to have husbands and fathers working': a working wife was presumably either a luxury for the affluent or an unpleasant necessity for the poor. ${ }^{84}$

Women members also doubted whether it was proper for mothers, especially those with young children, to work. A survey of section thinking about the care of children revealed that most considered working mothers were entitled to expect child care. However, when the matter was debated, at least one speaker at the women's conference thought that, on this matter at least, too much was said about the rights of women, 'when in fact without hesitation or discussion the rights of the child should come first'. ${ }^{85}$ When the 1969 women's conference called for more 
nursery schools, one delegate reported that her section believed employers should not be allowed to employ mothers with children under five, unless they supplied proper child care facilities. Another speaker went further and stated that unless a woman was in poverty she should stay at home during the first five years of her child's life. She asked:

What was the matter with women today? They did not deserve to be mothers. If they could not sacrifice five years for their children before the children went to school they did not know what they were missing. They were missing the relationship between child and mother. It was no wonder there were so many child delinquents when that relationship was missing. Forget about the money ... and stay at home until the children go to school. ${ }^{86}$

For most, the ideal marriage remained one in which the wife stayed at home while the husband worked. Moreover, one contributor to Labour Woman, while bemoaning the 'double burden' of the working housewife, believed that, no matter how willing husbands might be, there remained domestic tasks 'which wives must shoulder'. ${ }^{87}$

\section{The slow progress of equal pay}

If some doubted that mothers with young children should join the labour force, they all believed that gender should not dictate pay: indeed, by 1966 the call for equal pay was described as the 'hardy annual' of the women's conference. ${ }^{88}$ Labour had grappled with the issue for many decades. After the publication of a Royal Commission report on the subject in 1946, Clement Attlee's Cabinet declared that, while it was in favour in principle, the constraints imposed by post-war reconstruction meant it was impractical. ${ }^{89}$ In 1953 the party conference reaffirmed Labour's belief in the 'principle of equal pay for equal work' and committed a future government to 'immediately implement' the policy albeit only to government employees, to 'give a lead to industry generally'. ${ }^{90}$ Individual Labour MPs did their best to further the cause during the years of Conservative rule. In 1954 Houghton introduced a Private Member's Bill that sought to achieve equal pay by altering contracts of service. He was supported by MPs from across the party's leftright divide, including Barbara Castle. During this period individual unions and the Trades Union Congress (TUC) also passed resolutions supportive of the measure.

As a result, Labour's 1964 manifesto promised to implement women's right to 'equal pay for equal work', a commitment reaffirmed in $1966 .{ }^{91}$ Wilson's ministers were not, however, obliged to introduce equal pay immediately. At the 1963 party conference, the NEG indicated it would 
merely 'seek at an appropriate stage in its first term of office to consider ways and means of implementing' the policy. ${ }^{92}$ Ray Gunter, Minister of Labour between 1964 and 1968, was merely adhering to policy when, in January 1965, he appointed a working party of civil servants, drawn from his ministry, the Department of Economic Affairs and the Treasury, to consider the matter. The subsequent report, presented in November, was cautious to say the least, in no small measure owing to the Treasury's preoccupation with rising labour costs. In the first instance, the working party recommended equal pay should come through agreement between government, the unions and employers, as it was deemed important to maintain the tradition of free collective bargaining. It also cautioned against implementing any measure while economic circumstances remained so uncertain. The authors were obviously not keen on equal pay and repeated many of the misgivings expressed by the earlier Royal Commission. Thus, they feared it would encourage full-time female workers to go part-time; that married men with dependants would be relatively worse off; and - contradicting the first objection juvenile delinquency would rise through lack of a mother's presence in the home..$^{93}$

Despite its obvious scepticism, Gunter used the report as the basis for separate - and leisurely - talks with the Confederation of British Industry (CBI) and TUC. ${ }^{94}$ It was not until July 1966 that he convened a joint meeting with both bodies to agree a policy, something he must have known was unlikely. The TUC favoured the International Labour Organisation's definition of 'equal pay for work of equal value', while the CBI preferred the more restrictive European Economic Community's notion of 'equal pay for the same work', and neither side had moved from their original position since meeting the minister. ${ }^{95}$ If Gunter appeared in no rush to reach an agreement, the CBI employed blatant delaying tactics. At their first meeting with the TUC, employers' representatives claimed they had no mandate to agree a policy, as the CBI had not formally determined its position. The CBI debated the issue only in 1968 and then claimed it would need another year before it could arrive at a definite policy. Even Ministry of Labour officials thought that a 'stately pace'. ${ }^{96}$

As a result, by the end of 1967 equal pay was as far away as it had ever been. ${ }^{97}$ While Gunter tried to avoid responsibility, Labour women expressed frustration with his failure to deliver - although the NLWAC loyally defended the minister by stressing the complexity of the issue during a time of economic difficulty. ${ }^{98}$ Gunter was informed of a particularly striking outburst at a trades union meeting in Newcastle upon Tyne (at the heart of a region with little known sympathy for feminism), which occurred during a debate on a resolution that called for the immediate introduction of equal pay: 
The mover of the resolution complained in most bitter terms about the apparent lack of interest and inertia, from all responsible quarters. She very forcibly stated that women were not tied to be the 'law abiding' section of industry forever and a day, making reference to the fact, that the Engineering Industry in particular, had a backbone of women workers who could bring that industry to its knees... Other delegates speaking in support, reflected the rising anger and impatience of women workers through this ever continuing delay.... They warned that they will no longer tolerate any longer the role of industries [sic] second class citizens, or accept being the means of cheap labour. They ... declared, that they were very seriously thinking of emulating the old Suffragettes, as an indication of their determination to achieve this objective. ${ }^{99}$

\section{The impact of Barbara Castle (again)}

Wilson sacked Gunter in April 1968 and subsumed his ministry into what became the Department for Employment and Productivity (DEP), at the head of which, and enjoying the prestigious title of First Secretary of State, was Barbara Castle. She initially echoed her predecessor's position on equal pay, claiming to favour the principle but stressing the practical problems regarding implementation. As the measure entailed a 'significant increase' in wages, Castle ruled it out while the country's economic problems persisted. ${ }^{100}$ What seems to have encouraged Castle to revise this opinion was her responsibility for maintaining the government's incomes policy. ${ }^{101}$ This meant the DEP was forced to intervene in numerous complicated pay disputes in which equal pay was at least tangentially raised. It was this experience, she subsequently claimed, which 'fired my determination to force the male chauvinists in the Treasury to accept the principle of equal pay' and made her realise that, despite their rhetoric, the unions did not take the issue seriously.

The most significant of these disputes was the one involving 190 sewing machinists who installed car interior upholstery at the Fords Dagenham plant. ${ }^{102}$ In June 1968 these women went on strike believing they had been cheated by a job evaluation scheme, which they thought had not fairly graded their work. The scheme had taken months of tortuous negotiation to compile and involved a national joint council composed of the five unions with members in the factory. As the women complained only after the agreement had been signed, most unions were unwilling to address their concerns, as they feared the scheme would unravel as a result. The official inquiry into the dispute claimed the women were unconcerned with differentials between men and women on the same grade - and so did not call for equal pay. They were, however, unhappy about how their work as sewing machinists was 
graded in relation to other comparable occupations in the plant. The union representing most of the women endorsed this interpretation. Even so, some saw the matter otherwise. The Prime Minister received an anonymous note claiming to come from Dagenham which stated that 'we are fighting a great fight for equal pay for women ... we will force you to give us all equal pay, or strike with our unions' blessings, we're sorry for Fords, sorry for the men out of work, but more sorry for ourselves'. 'Give us what we want', the note demanded, 'not only us at Fords [but] all Women everywhere'. ${ }^{103}$

As the dispute held up vital car production, Castle tried to find a quick solution by intervening in person. She discovered that a shop steward had told the women there were two evaluation reports on their work, one of which (the one which allegedly favoured them) had been suppressed. This, Castle determined, was untrue and she convinced the women of it. Even so, to encourage an early return to work, the plant manager offered to reduce differentials between male and female workers on the machinists' grade. Ford had actually mooted this during negotiations but the unions rejected it because it entailed women undertaking shift work. As this could be squared with the government's prices and incomes legislation and would not force the collapse of the plant scheme, Castle approved the proposal, the women accepted it and the dispute ended.

The First Secretary was disappointed by the contribution of union representatives during the dispute. In her view some militants - particularly those associated with the engineering union - indulged in 'deliberate mischief'. Although they were ostensibly acting in support of equal pay, they appeared only to want to undermine delicate wage agreements. Her low view of the unions was confirmed by another dispute, during the autumn of 1968. Engineering employers had agreed with unions led by Hugh Scanlon that male skilled workers should have their pay increased to $£ 19$ a week, even though Scanlon knew that women employees - already at the bottom of the industry's pay scale would remain on just $£ 13$. Thus differentials between men and women would increase. Scanlon was denounced by a female member of his own negotiating team. As a result, he went back to the employers to demand more for women, only to be told no money was left. With a national strike in the offing, Castle became involved and persuaded the employers to announce that, while they were willing to increase their offer to women workers, this could be done only if they reduced what had been put on the table for skilled men. Faced with the choice of reducing or increasing differentials, Scanlon accepted the original offer. Castle commented that, after this, she knew 'left to themselves the unions would never do anything serious about equal pay': government had to legislate. 
In June the same year, Castle had wrung an important concession out of an embattled Chancellor of the Exchequer. Roy Jenkins faced defeat over an amendment to his Prices and Incomes Bill that had been tabled by Labour MPs led by Lena Jeger. This stipulated that settlements that included moves towards equal pay should be exempted from the provisions of the Bill. Jenkins feared this would undermine attempts to keep down wages, as any union worth its salt would exploit the loophole. Castle suggested that if he allowed her to announce that the government would implement statutory equal pay by 1975, the wind would be taken out of Jeger's sails without any immediate cost to the country. Grabbing hold of this lifeline, Jenkins agreed and his Bill was passed without the offending amendment.

While claiming the unions could not be trusted to win equal pay, Castle used the threat of industrial militancy to persuade ministerial sceptics that legislation was necessary. Certainly, DEP civil servants were unclear how they should present her case. According to one brief, Castle's initiative was meant to 'contain' union pressure for equal pay, while another indicated it was simply designed to 'make progress' to equal pay and made no mention of union pressure. ${ }^{104}$ Even so, when Castle met the CBI to call an end to the talks initiated by Gunter over two years before, she waxed lyrical about the 'mounting pressure' for equal pay. It was, she claimed, to ensure that 'orderly progress' could be made towards what Castle identified as an inevitable end that action was now required. ${ }^{105}$ When, in July 1969, Jenkins tried wriggle out of his earlier commitment and prevent the inclusion of equal pay in the Queen's Speech, she again cited militancy as an important influence on legislation. Castle told Cabinet they 'had run out of delaying excuses ... there would be a move to equal pay anyhow and it was far better that we should control it and get credit for it'. Giving legislation legal force only in 1975 was the 'maximum we could get away with'. More ominously, not to take a lead would mean trouble with the unions and the party: given the government's increasingly frosty relations with both, this argument could no longer be neutralised by the Treasury's line that equal pay was too expensive. ${ }^{106}$

\section{A very quiet revolution}

When finally debated in the Commons, equal pay had no enemies who were prepared to speak. Despite employers' hostility, the Conservatives decided not to oppose the measure, their own research having revealed that the majority of men and women supported it. ${ }^{107}$ On the Labour side only Renee Short complained about how long it would take for equal pay to become a statutory requirement. Apart from that, even she 
was complimentary: the Bill was, Short said, an 'important landmark in women's emancipation'. Perhaps because of this lack of opposition, as the former minister Fred Lee noted, the Bill went through 'practically without a ripple' in the press. On its third and final reading the chamber was almost empty. ${ }^{108}$

If the introduction of equal pay provoked little open hostility, it generated only a grudging welcome. The NLWAC was "not completely satisfied' with Castle's Bill, while the First Secretary was frustrated by the lifeless nature of the women's conference debate on the matter, even though it had just become law. She was more than a little annoyed by the response of fellow Labour women and tartly commented that it was 'another example of how our movement is so schooled in protest that it doesn't know how to celebrate victory'. This downbeat reaction was possibly due to the fact that, as Castle's deputy Harold Walked noted, the Bill marked only the 'end of the beginning' while, as she conceded, it was a 'long overdue piece of justice'. ${ }^{109}$

The final Act certainly left many issues unresolved and Castle was well aware of its limitations. It did not address women's unequal access to certain jobs and particular forms of training; on such matters the First Secretary admitted women would have to keep on pressing ministers. ${ }^{110}$ With further progress on that front in mind, as the Bill reached its last stage, Castle asked DEP officials to investigate the possibility of legislating against discrimination in employment and training. True to form, her civil servants opposed an early initiative, owing to its apparent complexity. ${ }^{111}$ Castle knew some would be disappointed that provision for equal pensions was also excluded from the legislation. She did her best, but had backed down in the face of the opposition of the Secretary of State for Social Security, Richard Crossman. Castle nonetheless kept options open by including in her Bill powers to deal with the matter sometime in the future. ${ }^{112}$ Finally, she had wanted to abolish restrictions on the hours women could work, but considered the unions would oppose proposals of that sort. Castle meant to pursue this after equal pay had become a reality. ${ }^{113}$

Echoing the voluntaristic emphasis noted earlier, Castle stated that equal pay legislation would have a profound effect on society only if women's attitudes also changed. In particular, more should join a union, as they 'had no right to expect the full fruits of the Bill unless they bestirred themselves to assert their rights and to organise'. She was, Castle claimed, merely providing them with a legal framework, 'not a system of spoonfeeding', and so they 'must not leave it all to the Government'. Even Short believed the Bill would have come sooner had women workers been more militant; the problem was, she conceded, that not all women appeared to want equality. ${ }^{114}$ As the NLWAC noted in 1968, many preferred 'a certain level of protection and discrimination, 
to an insecure freedom', such that opposition to divorce law reform, for example, was 'based less on an objection to easier divorce than on a concern for the social security of the wife divorced against her will'. ${ }^{115}$

Castle did not think the required change of attitude would come overnight. In particular, she believed women's lack of training was due less to problems of access and more to a 'fundamental problem of attitudes, including the attitude of women and girls themselves, of parents and others concerned with their career guidance and employment'. While something could be done about this through education, and the DEP itself was trying to change attitudes, 'we must expect that married women ... will continue to put family and home first and the job second; and what is more that society will expect this of them'. We have, she suggested, 'a long way to go to gain full public acceptance of the economic and social advantages of a workforce without divisions in responsibility and skill based on sex'. ${ }^{116}$

\section{Conclusion}

Given the detrimental influence the unions are thought to have had on Labour's attempt to appeal to women, it is ironic that the threat of industrial militancy helped Castle achieve equal pay. The critical role played by Castle in this process only adds to the paradox, for she had long avoided identifying with Labour's female wing, fearing, like fellow MP Jennie Lee, that would impede her advance in the wider party. ${ }^{117}$ In fact, the introduction of equal pay legislation owed little to Labour women: the NLWAC was consulted only after the Bill was drafted and then the CWO was given just time enough to respond in a personal capacity. ${ }^{118}$ If ineffectual in influencing policy, Labour's women's organisation was, as we have seen, no more proficient in boosting female party membership or support at the ballot box.

This chapter illustrates how far the contradictory impulses set in train by affluence were reflected in Labour's ranks. The party's female activists, who were mainly taken from an older generation of workingclass housewives, could be severely critical of those young enough to be their daughters - and sometimes granddaughters. Few were prepared to change their ways to pander to those they thought should listen to counsel offered by older and wiser heads. While such activists looked on husbands and wives as partners, with the latter rightly performing a mainly nurturing role, they agreed the nature of this relationship should be more egalitarian and they supported equal pay. That it was only in the Wilson governments' final months that this latter matter was definitively addressed suggests that not everybody in the party Ray Gunter and the unions in particular - looked on the subject with 
the same kind of seriousness exhibited by women's conference delegates. Indeed, the delayed enactment of equal pay was seen as further evidence of the party's lack of regard for women's interests. Yet, as the concluding chapter suggests, the response of female voters at the 1970 general election indicates that the promise of an equal wage with men was not as high on most women voters' lists of priorities as some of the country's few feminists wished.

\section{Notes}

The place of publication is London unless otherwise specified.

1 Report of the Thirty-Sixth National Conference of Labour Women (1959), p. 9.

2 See, for example, A. Black and S. Brooke, 'The Labour Party, women, and the problem of gender, 1951-1966', Journal of British Studies, 36:4 (1997); and M. Francis, 'Labour and gender', in D. Tanner, P. Thane and N. Tiratsoo (eds), Labour's First Century (Cambridge, 2000).

3 I. Zweiniger-Bargielowska, 'Explaining the gender gap: the Conservative Party and the women's vote, 1945-1964', in M. Francis and I. ZweinigerBargielowska (eds), The Conservatives and British Society, 1880-1990 (Cardiff, 1996).

4 Report of the Forty-First National Conference of Labour Women (1964), p. 53.

5 Thirty-Sixth Conference of Women, pp. 10-12 and passim.

6 Report of the Forty-Second National Conference of Labour Women (1965), p. 4; 'A women's section is formed', Labour Woman, 47:3 (1959), pp. 31-2.

7 J. M. Bochel, 'Activists in the Conservative and Labour parties. A study of ward secretaries in Manchester', MA thesis, University of Manchester (1965), p. 18.

8 This information is recorded in the annual reports of the party conference.

9 Report of the Fifty-Fourth Annual Conference of the Labour Party (1955), p. 69; Lambeth Archives, Brixton CLP papers, IV/156/1/3, GC minutes, 29 February 1956.

10 Bochel, 'Activists', pp. 21, 35.

11 London Metropolitan Archive (LMA), Southall CLP papers, Acc 1267/57, agent's reports, Report of general election campaign 1959.

12 Bristol Record Office (BRO), Labour Party South West Region papers, 38423/47, Bristol South, Annual reports for the years 1962/3-1969/70.

13 National Library of Wales (NLW), Brecon and Radnor CLP papers, 2, Brecon branch women's section minutes, 28 July 1970.

14 B. Castle, Fighting All The Way (1993), pp. 121-2.

15 NLW, Labour Party of Wales papers, file 126, Llanelli Federation of Labour Women's Advisory Council minutes, 3 May 1966; file 125, Llanelli Labour Women's Advisory Council aggregate minutes, 16 November 1966.

16 Labour Party Archive (LPA), National Executive Committee (NEC) Organisation Sub-Committee (OSC) minutes, 18 November 1958, Report of an enquiry, NAD/85/11/58.

17 West Yorkshire Archive, City of Bradford Labour Party papers, 60D84/2/4, Bradford South women's section minutes for 1958, passim.

18 Lambeth Archives, Clapham CLP papers, IV/156/2/5, Clapham Central women's section minutes for 1958, passim. 
19 See, for example, Southall CLP papers, Acc. 1267/14, Glebe ward women's section minutes, 12 December 1958.

20 Humber ward section, 'Women and the second industrial revolution', Labour Woman, 49:9 (1959), p. 124; British Library of Political and Economic Science, Merton and Morden CLP papers, 3/7, Morden ward women's section minutes, 10 June 1962.

21 South West Region papers, 38423/49, regional women's officer reports, 24 and 30 September 1970.

22 H. Jenkins, Rank and File (1980), p. 107.

23 Report of the Forty-Fourth National Conference of Labour Women (1967), p. 26.

24 Essex County Record Office, EC of the Labour Party Eastern Region, minutes, D/Z 215/1, 9 February 1952; National Labour Women's Advisory Committee (NLWAC) minutes, 4 February 1960, Women's organisation and activities, pp. 1-2; Report of the Forty-Fifth National Conference of Labour Women (1968), p. 5.

25 LMA, Labour Party London Region papers, Acc 2417/H/36/7, Regional women's officer report, 19 October 1967; Modern Records Centre (MRC), Labour Party West Midlands Region papers, MSS6/3/1/368, organiser's report.

26 South West Region papers, 38423/20, Whiles to Cox, 4 May 1966.

27 Report of the Thirty-Eighth National Conference of Labour Women (1961), pp. $47-8$.

28 Report of the Sixty-Seventh Annual Conference of the Labour Party (1968), pp. 119-28; Report of the Forty-Sixth National Conference of Labour Women (1969), pp. 35-6.

29 LPA, NEC minutes, 23 April 1969, B. Lockwood, Forty-sixth national conference of Labour women, NAD/W49/4/69.

30 NLWAC minutes, 2 June and 8 September 1960; NEC minutes, 23 March 1960, Interim report of the Salaries Sub-committee, pp. 8-10.

31 Tom Harrisson Mass-Observation Archive, Beveridge Social Services Survey, Box 2, File E, Interview with members of Park ward, North Tottenham, August 1947, and Report on Coleraine Labour Party women's section, Tottenham, August 1947.

32 BRO, Bristol West CLP papers, 38598/1/f, GMC minutes for 1968, passim; South West Region papers, 38423/46, North West Bristol CLP, Annual report 1966.

33 Forty-Fourth Conference of Women, pp. 33-7.

34 Forty-Fifth Conference of Women, p. 27.

35 Report of the Forty-Seventh National Conference of Labour Women (1970), p. 20.

36 Forty-Fifth Conference of Women, pp. 25-7; Labour Party, Women and the Labour Party (1971), pp. 3, 7, 9.

37 Labour Party, Is This a Portrait of You? (1961), and Don't Let Men Make All The Decisions! (1965).

38 Report of the Fortieth National Conference of Labour Women (1963), p. 38.

39 NLWAC minutes, 4 February 1960, Women's organisation and activities, pp. 3-4; 'Editor's letter', Labour Woman, 48:2 (1960), p. 14; 'Editor's letter', Labour Woman, 48:10 (1960), p. 118.

40 D. M. Loftus, 'A new look for Labour women', Labour Organiser, 39:458 (1960), pp. 150-2.

41 Forty-First Conference of Women, p. 3; Forty-Second Conference of Women, p. 3.

42 Fortieth Conference of Women, p. 4.

43 K. Butler, 'More about that new look', Labour Organiser, 39:460 (1960), pp. 187-8.

44 Forty-First Conference of Women, p. 28. 
45 Forty-Sixth Conference of Women, p. 18; R. Vincenzi, 'Playgroup', Labour Woman, 60:7 (1970), p. 140; West Midlands Region papers, MSS 6/3/1/289, 364 , organisers' reports.

46 Thirty-Eighth Conference of Women, p. 49; Fortieth Conference of Women, pp. 29-31; Forty-Third Conference of Women, p. 4.

47 'Editor's letter', Labour Woman, 48:10 (1960), p. 118; NLWAC minutes, 3 November 1960.

48 Merseyside Records Office, Toxteth CLP papers, 331 TLP/3, West Toxteth women's section minutes, 3 October 1959, 17 May, 23 and 30 October 1960.

49 P. Wilmott, The Evolution of a Community (1963), pp. 71-2.

50 M. Young and P. Wilmott, Family and Kinship in East London (Harmondsworth, 1986), pp. 49-50, 56.

51 Humber ward section, 'Women', p. 124.

52 London papers, Acc 2417/B/76/3/6, Clarion, 42:1 (1963).

53 Report of the Thirty-Seventh National Conference of Labour Women (1960), pp. 14-16.

54 Forty-First Conference of Women, p. 47.

55 Fortieth Conference of Women, pp. 12, 16.

56 West Midlands Region papers, MSS 6/3/1/350, organiser's reports; FortyThird Conference of Women, p. 38.

57 OSC minutes, 19 July and 13 December 1966.

58 Report of the Sixty-Seventh Annual Conference of the Labour Party (1968), p. 371; Forty-Seventh Conference of Women, pp. 4-5.

59 Forty-Seventh Conference of Women, pp. 1-5; Forty-Sixth Conference of Women, pp. 30, 34; NLWAC minutes, Outside contacts, 12 December 1969, NAD/ $\mathrm{W} / 114 / 12 / 69$.

60 M. Colquhoun, A Woman in the House (Brighton, 1980), pp. 10-11.

61 Labour Party, Women and the Labour Party (1971), p. 4.

62 Thirty-Seventh Conference of Women, pp. 44-5.

63 C. Collette, "Daughters of the Newer Eve": the labour movement and women', in J. Fyrth (ed.), Labour's Promised Land? (1995), pp. 47-9; idem, 'Questions of gender: Labour and women', in B. Brivati and R. Heffernan (eds), The Labour Party. A Centenary History (2000), p. 410.

64 Forty-Third Conference of Women, pp. 37-8; Forty-Fifth Conference of Women, p. 34.

65 Labour Party, Discrimination Against Women (1968), p. 20; Forty-Fifth National Conference of Women, pp. 29-30, 36.

66 N. Dennis, F. Henriques and C. Slaughter, Coal Is Our Life (1969), p. 165.

67 South West Region papers, 38423/18/2, Quarterly report - September 1967.

68 D. Fisher, 'Why not you?', Labour Woman, 60:8 (1970), pp. 154-5; FortyFourth Conference of Women, pp. 30-1.

69 Forty-Fifth Conference of Women, pp. 30-2.

70 Labour, Discrimination, p. 6.

71 Forty-Fifth Conference of Women, pp. 35-6.

72 OSC minutes, 17 July 1958; 17 January 1967, Resolutions, NAD/15/1/67; 18 March 1969, Resolutions, NAD/40/3/69; 15 April 1969, Resolutions, NAD/54/4/69; 7 December 1970, Resolutions, NAD/84/12/70.

73 Unless otherwise stated, this account is based on LPA, Discrimination Against Women Study Group papers.

74 New Statesman, 9 June 1967.

75 Forty-Fifth Conference of Women, p. 31.

76 MRC, Handsworth CLP papers, MSS 8/5/21, Labour Party Research Department, Participation '69. Women and social security: a short report, Information Papers, No. 50, February 1970. 
77 R. Crossman, The Diaries of a Cabinet Minister. Volume II (1977), p. 668.

78 For more on this see P. Thompson, 'Labour's "Gannex conscience"? Politics and popular attitudes to the "permissive society", in R. Coopey, S. Fielding and N. Tirasoo (eds), The Wilson Governments, 1964-70 (1993).

79 Forty-Seventh Conference of Women, pp. 64-7; NLWAC minutes, 12 December 1970.

80 G. Colman, 'Women as citizens', Labour Woman, 47:2 (1959), pp. 19, 26; 'Women as wage-earners', Labour Woman, 47:3 (1959), pp. 33, 40; and 'Women as housewives', Labour Woman, 47:4 (1959), pp. 47-8.

81 Forty-Sixth Conference of Women, p. 22.

82 Thirty-Sixth Conference of Women, pp. 22-3.

83 Thirty-Seventh Conference of Women, p. 7; Forty-First Conference of Women, pp. 18-19.

84 Forty-First Conference of Women, p. 15.

85 Forty-Third Conference of Women, pp. 28-32.

86 Forty-Sixth Conference of Women, pp. 24-5.

87 MGH, 'Working wives', Labour Woman, $48: 3$ (1960), p. 27. Emphasis added.

88 Forty-Third Conference of Women, p. 18.

89 J. Tomlinson, Democratic Socialism and Economic Policy (Cambridge, 1997), pp. 199-203.

90 Labour Party, Challenge to Britain (1953), p. 29.

91 Labour Party, Let's Go with Labour for the New Britain (1964), p. 10, and Time for Decision (1966), p. 14.

92 Report of the Sixty-Second Annual Conference of the Labour Party (1963), pp. 262-3.

93 Public Record Office (PRO), LAB 10/2382, Draft report of working party on equal pay, July 1965; LAB 10/2514, Report of working party on equal pay, n.d. (but November 1965); LAB 10/2529, Johnston to Garcia, 28 July 1965, and Johnston to Maston, 13 August 1965.

94 LAB 10/2582, Ministerial Committee on Economic Development, 24 January 1966, and Equal pay. Memorandum by the Minister of Labour, 14 January 1966 .

95 LAB 10/2582, Brief for Parliamentary Secretary, Joint meeting with the TUC and CBI on equal pay, 18 July 1966; Note for the record, equal pay, 6 May 1966; and note for the record, equal pay, 25 April 1966.

$96 \mathrm{LAB}$ 10/2878, Draft note of a joint meeting with representatives of the TUC and CBI on equal pay, 18 July 1966; LAB 10/3291, Memo by N. Singleton, 3 January 1968.

97 LAB 10/2878, Press notice on equal pay, 7 December 1967; LAB 10/3131, Equal pay, note of a meeting between Mr. Hattersley and representatives of the CBI and the TUC, 7 December 1967.

98 Forty-Fourth Conference of Women, pp. 74-5, 77-8.

99 LAB 10/2396, General Secretary, Newcastle and District Trades Council to Gunter, 9 November 1967.

100 LAB 10/2396, Castle to the Secretary, Battersea Labour Party, n.d. (but April 1968).

101 Unless otherwise stated, the following account is based on B. Castle, The Castle Diaries, 1964-76 (1990), pp. 233, 235, 238-9, 265-8, 353-4, 357-8, 400, 402; and Castle, Fighting, pp. 409-12, 427.

102 For background to the dispute, see Report of a Court of Inquiry under Sir Jack Stamp into a dispute concerning sewing machinists employed by the Ford Motor Company Limited (August 1968, Cmnd 3749).

103 PRO, PREM 13/2412, letter to Wilson, June 1968. 
$104 \mathrm{LAB}$ 10/2878, Equal pay, brief for the First Secretary for a meeting with the TUC on 31 July 1968 to discuss a phased programme for the introduction of equal pay; LAB 10/3310, Equal pay, brief for the First Secretary for a meeting with the TUC on 31 July to discuss a phased programme for the introduction of equal pay.

105 LAB 10/2878, Note for the record, equal pay - meeting with the CBI, 23 July 1968.

$106 \mathrm{LAB} 43 / 544$, Equal pay, memorandum by the First Secretary of State and Secretary of State for Employment and Productivity', n.d.

107 Bodleian Library, Conservative Party Archive (CPA), CCO 180/33/1/1, ORC, A survey of women's interests and problems, March 1968.

108 Parliamentary Debates (Hansard), 5th Series, Volume 800, House of Commons Official Report, Session 1969-70, columns 753, 759-60, 762.

109 Ibid., columns 754, 771.

110 Forty-Fourth Conference of Women, pp. 73-4; Forty-Seventh Conference of Women, pp. 14-16; M. Rendel, 'How equal pay works', Labour Woman, 60:4 (1970), pp. 65-6.

$111 \mathrm{LAB} 43 / 568$, Press notice of speech to Women's Consultative Committee, 25 November 1969, and letter, Castle to Wilson, 25 March 1970; LAB 43/ 577, Memo from D. B. Smith, 23 April 1970.

112 LAB 111/11, Crossman to Castle, 25 February 1970; Shackleton to Castle, 9 March 1970; Note of meeting between the First Secretary and the TUC Employment Development Policy Committee, 11 May 1970; Treatment of pension rights under the Equal Pay Bill, 13 May 1970; Draft paper for the Social Services Committee, treatment of pension rights under the Equal Pay Bill, 13 May 1970.

113 LAB 43/545, Smith to Barnes, 25 September 1969.

114 Hansard, 5th Series, Volume 800, Session 1969-70, columns 770-2, 775; ThirtyNinth Conference of Women, p. 18; Forty-First Conference of Women, p. 34; FortySeventh Conference of Women, p.19.

115 Labour, Discrimination, p. 5.

116 LAB 43/568, Press notice for speech to Women's Consultative Committee, 25 November 1969; Castle to Wilson, 25 March 1970.

117 P. Hollis, Jennie Lee. A Life (Oxford, 1997).

118 NLWAC minutes, 12 December 1969. 